
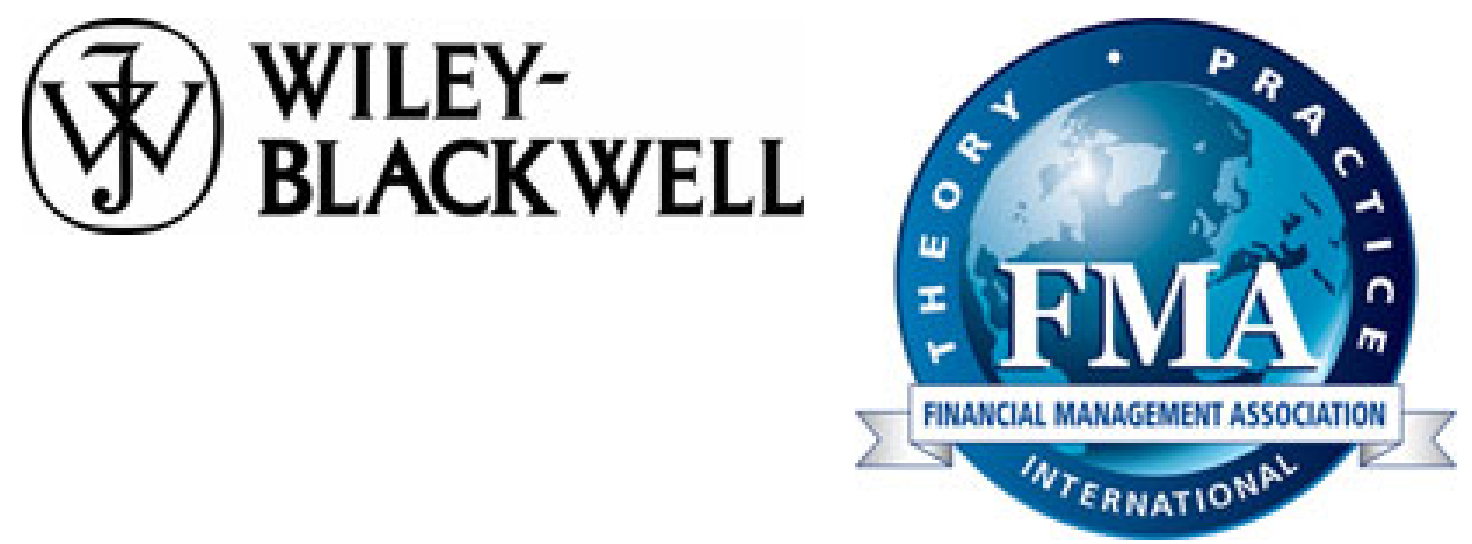

Managerial Reputation and Corporate Investment Decisions

Author(s): David Hirshleifer

Source: Financial Management, Vol. 22, No. 2 (Summer, 1993), pp. 145-160

Published by: Blackwell Publishing on behalf of the Financial Management Association International

Stable URL: http://www.jstor.org/stable/3665866

Accessed: 18/02/2011 17:23

Your use of the JSTOR archive indicates your acceptance of JSTOR's Terms and Conditions of Use, available at http://www.jstor.org/page/info/about/policies/terms.jsp. JSTOR's Terms and Conditions of Use provides, in part, that unless you have obtained prior permission, you may not download an entire issue of a journal or multiple copies of articles, and you may use content in the JSTOR archive only for your personal, non-commercial use.

Please contact the publisher regarding any further use of this work. Publisher contact information may be obtained at http://www.jstor.org/action/showPublisher?publisherCode=black.

Each copy of any part of a JSTOR transmission must contain the same copyright notice that appears on the screen or printed page of such transmission.

JSTOR is a not-for-profit service that helps scholars, researchers, and students discover, use, and build upon a wide range of content in a trusted digital archive. We use information technology and tools to increase productivity and facilitate new forms of scholarship. For more information about JSTOR, please contact support@jstor.org.

Blackwell Publishing and Financial Management Association International are collaborating with JSTOR to digitize, preserve and extend access to Financial Management. 


\title{
Managerial Reputation and Corporate Investment Decisions
}

\author{
David Hirshleifer
}

David Hirshleifer is an Associate Professor of Finance at the Anderson Graduate School
of Management, University of California at Los Angeles, Los Angeles, California.

- During the 1980s, General Motor's Chairman and CEO Roger Smith undertook vast capital expenditures, and pursued his vision of GM as a leader in new production techniques and labor management. This included $\$ 40$ billion in new equipment between 1979 and 1987 (see Business Week, May 18, 1987), the self-consciously innovative development of the Saturn line of cars, and the introduction of robotic production methods. In hindsight, the disastrous consequences of these policies are evident to all. At the time, however, there was more room for controversy. It was plausibly argued by some that massive investment and innovative expenditure was needed to meet the competitive challenge of the Japanese car manufacturers. And as GM's market share and productivity fell, it was pointed out that radical change is costly, that the payoff to innovation often does not arrive in the short-term, and that courage was needed to revolutionize the American car industry. As Roger Smith put it, "Don't write the book on me until I've

I thank Tarun Chordia and especially the editor, Anjan Thakor, for helpful comments. been gone at least ten years. It's too early. You've got to wait and see." (Lee [30])

Although Smith made the wrong call, Smith's reputation as a manager benefited from the fact that he was following a very long-term investment strategy. As a consequence, early signs of failure (declining market share, low profitability) were not judged as harshly as they would have been if his policies were designed to generate immediate performance, and still failed. Since his strategy arguably had great long-term promise, not everyone knew just how badly things would turn out.

This case leads one to suspect that managers will sometimes intentionally choose investment strategies that take a long time to evaluate fairly. ${ }^{1}$ In some cases, this may be

\footnotetext{
'If a manager can avoid looking bad by following a long-term strategy, why don't all managers do it? For one thing, a superior manager may want his project outcome to be resolved early, which demonstrates his high ability to investors sooner. Given that managers who believe they are superior prefer early-resolving projects, a manager who knows he is not superior faces a tough choice. By choosing a long-term strategy like Roger Smith's, he can avoid a visible early failure. But since top managers
} 
because long-term investments are the most efficient for the firm. In others, it may be that long-term investments are inefficient for the firm, but they are chosen because they afford the manager protection from the risk of being viewed as a failure early on.

This example is a special case of a more general point. This article is based on the fundamental fact that a manager's investment decisions affect his reputation. Even President Clinton has staked his reputation on the strategy he is designing for U.S. government spending and investment. Because of a concern for reputation, managers sometimes make investment choices that are bad for shareholders but good for the manager - because they make the manager look good in the short run.

Managers have good reason to be concerned with maintaining their reputations for high ability, both in the short run and the long run. Apart from direct value of prestige, high reputation gives the manager better bargaining power to increase his pay. Even if a manager's sole purpose were to maximize shareholder value, he may be concerned with the firm's reputation. Investors' beliefs about his ability and his firm's assets and capacities will affect the price at which the firm can raise capital, hire employees and sell its products.

Managers often have information about the profitability of alternative investment decisions that is unavailable to outside investors. Furthermore, investors cannot perfectly observe the manager's investment choices. This gives the manager leeway to follow policies that do not maximize profitability in the long run, but improve the manager's immediate reputation. For example, the manager of a pharmaceutical firm may invest heavily to accelerate approval of a medication, if testing and FDA approval will reflect well on him. This can hurt shareholders if the cost is disproportionate. Another example is a consumer retail chain cutting investment in store quality and customer service in order to make earnings seem high in the short run.

This article reviews research on the manipulation by managers of investment decisions owing to a desire to influence perceptions about a manager or firm, and in particular, with reputational effects on investment deci-

try to choose projects whose outcomes are visible early, the very lack of early resolution, at least to some extent, tips investors off that the manager is inferior. Still, as will be discussed later, even a good manager can have good reason to pick a long-term, late-resolving project. In other words, promising a rosy future is the last refuge of incompetence; but some managers who promise a rosy future are, in fact, telling the truth. sions. ${ }^{2}$ The term "reputation-building" is more general than the concept of "signalling" introduced in academic models of capital structure in the 1970s. One could define signalling as any action taken by a manager that conveys information to others, but this does violence to the term. The basic notion of signalling is taking a visible action (such as choosing a capital structure) for the primary purpose of conveying information to others. More generally, even hidden actions have consequences that are eventually visible, so reputational considerations affect firms' hidden investment decisions (such as customer service activities) even though these decisions are not used as signals. Also, reputational considerations affect important decisions, such as whether to undertake a major new project, even though the primary motivation for the project may be profitability.

The main lessons of the paper can be summarized as follows. Managers have an incentive to use investment choices as a tool for building their personal reputations or the reputation of their firms. These incentives come in three main forms: visibility bias, which encourages a manager to try to make short-term indicators of success look better; resolution preference, which encourages a manager to try to advance the arrival of good news and delay bad news; and mimicry and avoidance, which encourages a manager to take the actions that the best managers are seen to take, and to avoid the actions the worst managers are seen to take.

These incentives imply a variety of investment biases. These include: secretly squeezing investment so that shortterm cash flows look higher; liquidating assets prematurely to reveal that they are worth a lot; undertaking unprofitable investments to try to make it seem like a firm with good projects available; undertaking investments whose outcomes will be resolved soon, to reveal that you are a good manager; undertaking investments whose outcomes will be resolved in the distant future, to conceal the fact that you are a mediocre manager; avoiding profitable projects that have a high risk of early failure, to protect short-term reputation; hedging on corporate account, to reduce reputational risk; avoiding marginally profitable new projects, since investors will attribute low profitability to a lack of managerial talent; escalating bad projects, to avoid conceding that failure has occurred; conforming to the decisions of other managers, to avoid seeming unreliable, or in order to be judged against a comparable bench-

\footnotetext{
${ }^{2}$ For a brief exposition of how other decisions are influenced by reputation, see Hirshleifer [21].
} 
mark; and deviating from other managers, in order conceal mediocrity.

Thus, reputation-building affects the firm's attitude toward risk, what projects it undertakes and terminates, whether it obtains resolution of project outcome early or late, and whether it chooses the same projects as or different projects from industry competitors. Some researchers have developed models of reputation-building with implications that seem consistent with recent allegations that U.S. business underinvests, avoids risk excessively, and is too conformist. However, taken as a whole, the theoretical and empirical research on this topic neither substantiates nor disproves these claims.

The remainder of the paper is structured as follows. Section I discusses the motives for a manager to use investment policy as a tool for building reputation - of himself or his firm. Section II provides a taxonomy of different kinds of reputational distortions that can arise from reputation-building incentives. Section III then analyzes four different kinds of applications: cash flow manipulation (Section III.A.), risk manipulation (Section III.B.), projects transitions (Section III.C.), and conformism/fads in investment (Section III.D.). Section IV concludes and provides recommendations for investment policy.

\section{Why Managers Want to Build Their Reputations}

Consider a manager who decides today whether to invest or not to invest. ${ }^{3}$ Investors do not know whether the manager (or his firm) is of high or low quality, so his action will, in general, affect his reputation and that of his firm. After the decision is made, public news may arrive that will affect investors' beliefs about the manager and his firm. This is the "short-run" reputation he will be concerned about. Long-run profitability also matters to the manager, but not as much as to a shareholder planning to buy and hold.

Only in the last decade have academic researchers begun to explore the more general consequences of managerial reputation-building. This recent interest has been led by Bengt Holmstrom in two important papers (Holmstrom [25] and Holmstrom and Ricart i Costa [26]). Holmstrom and Ricart i Costa [26] point out that the manager's freedom to quit a firm to get higher pay else-

\footnotetext{
${ }^{3}$ The alternatives may also be whether to invest a larger or smaller amount, whether to invest in a high- or low-risk project, whether to follow the investment policy of other managers or to deviate, and so on.
}

where gives him an incentive to build his reputation in the short run. This contrasts with a more traditional analysis of agency problems that assume that the manager and the firm are inseparably bound together. ${ }^{4}$

It is worth pointing out that shareholders may actually want the manager to invest in a way that improves the firm's short-run reputation, even if this is at the expense of long-run profitability, for at least three reasons (see Harris and Raviv [20], Thakor [46], and Trueman [47]). First, some shareholders may expect to be selling their shares at the current market price before the long term happens. Second, if the firm plans to issue new equity, a better reputation allows it to do so at a higher price, to the benefit of current equityholders. Third, the price at which the firm is sold in a takeover contest can be improved by maintaining a good reputation (Stein [43]).

As an example of reputation-building, a firm may act to boost its current cash flows at the expense of reducing future cash flows by a greater amount. It can do so by failing to make a desirable investment, or even by liquidating an investment. Advancing cash flows incurs real costs in an attempt to redistribute wealth from new share purchasers to old. This is a trap, because if investors have rational expectations, they will not be fooled, on average, about the value of the firm. But the firm still needs to manipulate its investment policy (boost current cash flows). If it were to fail to do so, its cash flows would look low, and investors would wrongly believe the firm was worse than it really is.

In economic jargon, reputation-building creates deadweight costs. These costs are ultimately borne by the firm's founder when he initially sells his equity in the firm. Buyers will pay less for his equity since they can foresee that resources will be wasted on reputation-building.

In principle, it would be desirable to eliminate these deadweight costs by paying the firm's manager only for long-term performance, not short-term reputation (Dybvig and Zender [15]). Unfortunately, this is not as easy as it looks, for several reasons. First, a manager whose reputation is riding high has a credible threat to leave for another firm, so it may be impossible to hold his pay down while waiting to learn the long-term outcome. Second, the manager needs to consume while he is young. Although some of his compensation can be long-term, much of it must be

\footnotetext{
${ }^{4}$ Bethel [4] has extended these ideas by pointing out that the pressure on the manager to build his short-term reputation depends on the extent to which his decisions and performance at one firm can be observed at another firm.
} 
paid before his long-term performance is known. Third, as pointed out by Pound [38], there is a temptation on the part of the manager and the board to renegotiate contracts later, so that a manager with favorable information can increase his pay by conveying favorable information about the firm.

This essay does not focus on designing contracts to deal with reputational incentives. Generally, one would expect that compensation schemes could be designed to mitigate unfortunate reputational problems partially, but not perfectly (e.g., Hagerty, Ofer, and Siegel [17]). Reputation has its good side as well, since a major motivation for working hard is to maintain a good reputation. Gibbons and Murphy [16] point out that a manager has a greater incentive to work harder when far from retirement because he will bear the reputational consequences of his effort for a longer time. Thus, compensation contracts should be more performance-sensitive for managers close to retirement. They provide evidence supporting this prediction.

\section{A Taxonomy of Reputational Pressures}

This section provides a taxonomy of the different kinds of reputational pressures that managers face. It also analyzes how these different kinds of pressures interact; these interactions show up repeatedly in the applications of Section III.

\section{A. Distortions}

There are three main ways in which managers can manipulate investment decisions to improve their reputations. First, managers can take actions that make the current or short-term news about project outcome appear more favorable - visibility bias. Second, managers can try to accelerate the arrival of news that is likely to turn out good, and delay the arrival of news that is likely to turn out bad - resolution preference. Third, managers can try to imitate the investment choices expected of good managers, and diverge from the choices expected of bad managers mimicry and avoidance. Let us consider each of these points in turn. 5

\section{Visibility Bias}

Visibility bias is defined as improving what is immediately visible, at the expense of what is not immediately visible. When dressing for a formal dinner, we spend more time choosing our pants than our underwear.

\footnotetext{
${ }^{5}$ This categorization is also discussed in Hirshleifer [21].
}

This makes what is visible look good. This can be profitable even if it occurs at the cost of what is not visible (fancy tie, cheap underwear). Cosmetic surgery and steroid muscle building are other examples. These improve appearances, at the expense of a less visible substance (future health). A similar point applies more mildly to high heels, cosmetics, and shoulder pads. And wearing fine suits and fashionable dresses conveys an impression of the wearer's wealth, while at the same time reducing it. These behaviors are all examples of visibility bias.

Visibility bias applies to investment decisions as well. Consider a project about which public news is about to appear, such as early sales figures on a new product. The manager has an incentive to improve appearances by increasing the favorability of more visible events, for example, by offering hidden discounts on the new product to boost initial sales. He will try to distort early news reports favorably, even if this leads to an equal decrease in the favorability of permanent performance. To see why, suppose that no one but the manager is aware of his ability to offer hidden discounts. Then he receives a benefit from improved reputation now. The ultimate reduction in his reputation later is to the correct level. Thus, he receives an early reputational benefit without paying any later reputational cost.

\section{Resolution Preference}

(i) Putting Your Best Foot Forward. On an interview or a date, one always puts one's best foot forward. And although the saying doesn't mention it, this is the same as putting one's worst foot backwards. A project manager should do likewise. Thus, other things equal, if he expects good news to arrive (he may not be sure), he should try to advance the date at which that news will arrive. If he expects bad news, he should delay resolution of the project. This "putting your best foot forward" effect is an example of resolution preference, because the manager wants to shift resolution of uncertainty about the project forward or back (see Hirshleifer and Chordia [22]).

(ii) Risk Avoidance. If the manager dislikes personal risk, then there is an advantage to deferring resolution of uncertainty. Even for a good manager, there is an appeal to not being judged until ten years after retirement (as is suggested by the Roger Smith quote at the beginning of this article). By deferring the resolution of uncertainty, the manager temporarily maintains his reputation at the 
current level, and reaps the rewards at the current level. His current reputation is based on the current assessment of his ability. Deferred resolution makes his lifetime income more certain than if his reputation and pay were to jump up or down with an immediate news event.

\section{Mimicry and Avoidance}

If people expect a high-quality firm to undertake ambitious investments, then a low-quality firm can try to mimic. Consequently, a high-quality firm may be led to exaggerate those investments that are difficult or costly for lowquality firms to mimic. Trueman [47] has pointed out that firms with low-quality investment opportunities may overinvest in order to seem to be firms with high-quality investments. Firms with high-quality investments also invest too much, in order to avoid being identified with the lower-quality firms! All firms are forced to overinvest. Since everyone knows this, they are not actually fooling anyone by doing so. But if a firm were to invest at the lower scale that is optimal for shareholders, investors would not give it any credit for doing so. Instead, they would assume that the firm had very poor investment opportunities.

Even if the investment choices are not visible to financial markets (such as expenditures on customer service and maintenance), mimicry and avoidance can be important. These will still occur, because the consequences of the investment decision (e.g., how favorable early news events are, or how early or later uncertainty about the project is resolved) are visible.

\section{B. How Reputational Pressures Interact}

Visibility bias and resolution preference should be viewed as the more fundamental management pressures, with mimicry and avoidance acting as a modifier. For example, suppose that some firms (efficient organizations) can provide hidden service to customers more effectively than others (inefficient organizations). For either type of firm, visibility bias leads to a temptation to secretly cut costs by reducing the quality of service. This boosts current net cash flows, and the long-run cost to the firm is not immediately visible. Suppose, however, that there is a positive probability that customer dissatisfaction will be discovered early by analysts and publicized widely. Then an efficient organization may maintain a superb level of service in order to demonstrate its high efficiency. If mimicry is too costly, an inefficient firm may still have low levels of service. On the other hand, the inefficient firm may also maintain customer service in order to avoid appearing even worse than it really is.

A wise epigram states that "It is better to be silent, and be thought a fool, than to speak and remove all doubt." Investment choices can also speak or remain silent, in the sense of leading to early news arrival or late news arrival. Resolution preference can pressure managers to make investment choices that either defer or advance resolution of uncertainty (Section II.A.2(i) above). A clever manager, who can reasonably expect his investments to succeed, may well want to "speak up" by undertaking projects whose outcomes will be resolved early. A foolish manager, whose projects are likely to fail, may do best with longterm, visionary projects whose outcomes will take a long time to resolve (as with the case of Roger Smith at the beginning of this article).

If this were the whole story, then managers would be treated extremely skeptically when news arrives late, because investors would know that news arrives early for good managers and late for bad managers. Suppose that managers perfectly control the timing of arrival of news. Then mimicry rears its ugly head, because late resolution of uncertainty will provoke such intense skepticism that even a bad manager or firm will be forced to advance resolution of uncertainty, just like good managers. In other words, a good manager puts his best foot forward. The bad manager has a bad foot, but if he doesn't step up, he is known to be bad. The best he can do is step up (with an early-resolving project) and hope to be lucky enough to get a good outcome.

More generally, however, managers do not have perfect control over when news arrives. Even a good manager who tries to advance resolution of uncertainty will sometimes find that it remains unresolved for a long period of time. A pharmaceutical company developing a blockbuster drug may find that the FDA insists on additional controlled studies before it will decide whether to approve. Alternatively, there may be strong business reasons to pick a project with long-term resolution. A pharmaceutical firm may take a long time to find out whether it is successful if it is trying to develop a new class of drugs or a new approach to finding drugs. But this may be more profitable for shareholders than to focus on developing routine variations on current drugs. Outsiders can't be sure if the firm's late resolution of uncertainty is because expected profits are higher from the late-resolution project, or because the firm wants to conceal its incompetence. Thus, a low-ability manager can intentionally defer resolution without being unambiguously exposed. External factors that affect reso- 
lution timing ease the pressure on low firms to mimic, so the manager can to some extent get away with pulling his worst foot backward. Thus, the epigram's recommendation to "remain silent" (avoid resolution of uncertainty) can be a valid one for low-quality managers and firms (Hirshleifer and Chordia [22]).

The choice of project affects not only when news arrives, but how noisy that news is as an indicator of firm or manager quality. For example, the success of a direct investment in Eastern Europe is subject to political risk that is outside the firm's control. Thus, holding other things constant, the project will tend to provide less resolution of uncertainty about the manager than a project whose outcome depends less on external factors than on the manager's ability.

The examples of the pharmaceutical firm and of the internationally investing firm illustrate choices between different kinds of projects with early or late resolution. Even for a given project, it is usually possible to advance or defer resolution. For example, by intensifying investment in R\&D, it is possible to complete development of a new product earlier; conversely, a weak product's introduction can be delayed. This implication of resolution preference is consistent with evidence of Chaney, Devinney, and Winer [11] and of Zwiebel [51], who find that the introduction of a new product is, on average, associated with a positive abnormal stock return. This suggests that, on the margin, there is a reputational incentive to introduce a new product prematurely.

If a new product is expected, then its introduction advances resolution of uncertainty. Thus, conventional product development expenditures will generally advance resolution of uncertainty about the firm. In contrast, an increase in basic research activity defers resolution of uncertainty. Investors will view managers who undertake visionary programs with skepticism ("What has all that investment produced so far?"). This skepticism will tend to pressure firms to invest too little in basic research from the viewpoint of shareholders (as well as society). However, a low-ability manager may follow the opposite strategy, since he expects resolution to be unfavorable to himself or his firm.

Thus, resolution preference has the perverse effect of assigning routine, conventional projects to the very best managers (who are eager to demonstrate their prowess as quickly as possible), while visionary, late-resolving projects tend to be undertaken by inferior managers who want to leave investors in doubt (see Hirshleifer and Chordia [22]). The disasters that may be associated with this kind of investment bias may be no less than monumental. The case of Roger Smith at GM was mentioned earlier. And, as Michael Jensen discussed in his 1993 presidential address to the American Finance Association, managers of sinking firms often claim that greater investment is needed to withstand the challenges of global competition, even when retrenchment is the appropriate response.

\section{Four Applications}

I now illustrate the effects of favorability bias, resolution preference and mimicry with four applications to examine: cash flow manipulation (Section III.A.), risk manipulation (Section III.B.), projects transitions (Section III.C.), and conformism/fads in investment (Section III.D.). These categories are thoroughly intertwined. The behavior of a manager who refuses to undertake a desirable risky project may be viewed as "myopic" (too reluctant to sacrifice current cash flow to increase future cash flow), conservative (too reluctant to bear risk), and resolutionaverse (too unwilling to take an action that will generate new public information). Clearly, care is needed in isolating the different effects.

\section{A. Cash Flow Manipulation}

This section examines how managers will shift cash flows over time in order to improve their reputations. I distinguish between the case in which the decision to invest (sacrifice current cash) is hidden, and in which it is visible. If the sacrifice of cash is hidden, then investment may cause the manager's reputation to suffer, because the market may attribute a low cash flow to low managerial ability. If the decision to invest is observable, then at least the manager receives credit for the likelihood that his action will generate greater cash flows in the future. Even taken as a given that the act of investing is observable, this section will explain why either underinvestment or overinvestment can occur. The predictions of reputational theories are discussed in the light of empirical evidence on the effect of the market for corporate control on firms' $R \& D$ expenditures.

\section{Hidden Investment}

An investment is hidden if investors cannot distinguish perfectly whether a reduction in cash flow today is associated with generating a higher cash flow in the future (investment), or just that past commitments have led to a high expense. For example, a firm's payroll expense may be high because the manager is not good at bargaining with his employees. On the other hand, the payroll expense may 
be high because the manager is hiring and training superlative personnel who will generate greater customer satisfaction, which will translate into high cash flows in future years.

Most managers claim that they are doing a good job, and can make very plausible cases for their game plans. It is hard to evaluate how good a job they are doing, which is one of the reasons that managers doing bad jobs are able to hold on to power for so long. As a result, investors are naturally skeptical. Nothing is more effective in assuaging that skepticism than the clink of hard cash on the table.

Better managers generate higher cash flows on average. Thus, hidden investment decisions that modify short-term cash flows affect the firm's and manager's reputations. This leads to a bias on the part of the managers in favor of short-term results, i.e., increasing early cash flows at the expense of ultimate profitability (visibility bias) (Narayanan [35]). A possible symptom of this bias is the use of seemingly irrational capital budgeting techniques that discount future cash flows excessively, such as the use of above-market discount rates or the use of the payback criterion (Narayanan [36]) ${ }^{6}$

To explain Narayanan's [35], [36] reasoning in more detail, suppose that interest rates are zero, and suppose that a manager can advance the arrival of a $\$ 10$ cash flow by one year through a hidden action, such as cutting back on maintenance spending or customer service. At date 1 , his cash flow is $\$ 110$ instead of $\$ 100$. This leads to an unambiguous reputational gain for the manager at date 1 . Under a set of technical assumptions that more or less "level the playing field," advancing the cash flow yields a net gain for the manager, because he receives the reputational benefit early, and no reputational cost later on. At date 2, his cash flow is correspondingly reduced, perhaps from $\$ 120$ to $\$ 110$. Since the shift increases the manager's reputation at date 1 , if date 2 is even a wash, the manager likes the shift.

How is the manager's reputation affected at date 2 ? On the one hand, the date 2 cash flow is lower by $\$ 10$, hurting his reputation. But on the other hand, everyone remembers his cash flow from last year, which was higher by $\$ 10$. Under not implausible assumptions, it turns out that these two effects cancel out, so that the manager's date 2 reputation is unaffected by the change. ${ }^{7}$ Thus, the manager

\footnotetext{
${ }^{6}$ One thing is puzzling about this explanation for the use of these techniques. If the goal is to look good in the eyes of the market, why don't firms try to conceal the fact that they are using capital budgeting techniques that overemphasize early cash flows?
}

likes the cash flow shift because of its effect on his early reputation. Even if the cash flow shift is costly, he may want to make it. ${ }^{8}$

Cash flows and earnings are normally positively correlated over time, so that the current cash flow is both a measure of current performance and a forecast of future performance. Depending on how strongly correlated cash flows are, the current cash flow may be a strong or weak forecaster of future prospects. Expectations of future cash flows can be either strongly or weakly sensitive to current cash flows. The greater the sensitivity, the stronger the reputational pressure to boost current cash flows (Stein [42]). However, the implications of this for the behavior of different kinds of firms is complex. For a growth firm, there is a great amount of uncertainty about the future, so potentially current cash flows convey a great deal of information. On the other hand, at the very early stages, cash flows may be almost irrelevant, because the firm has not yet begun to reap any rewards from its initial investments. For a mature firm, cash flow fluctuations may be transient. On the other hand, they may be indicators of whether the business is starting to decline.

An alternative reasoning that can yield the conclusion of a preference for short-term cash flows is based on the possibility that firms attempt to maximize the current stock price (Paul [37] and Thakor [46]). In Paul [37], the stock market is able to observe imperfect signals about the firm's future cash flows. The manager invisibly allocates resources between a long-term and a short-term project. ${ }^{9}$ If the signals available to the market about short-term cash flows are better predictors of the firm's total profitability than the market's signals about long-term cash flows, the firm shortchanges the long-term project. In the reverse circumstance, the firm will invest too heavily long-term. Thakor [45] provides an alternative explanation for the use of capital budgeting techniques that overemphasize early cash flows. The explanation is that internal cash flow has high value to a firm that attempts to maximize its current

\footnotetext{
${ }^{7}$ In other words, total cash flows (date $1+$ date 2 ) are the same as if no distortion had occurred.

${ }^{8}$ Extending the work of Harris and Holmstrom [19], Narayanan also examines a setting in which a manager who dislikes risk is protected from damage to his reputation through a downward rigid wage schedule. In such a setting, the manager will still try to improve his reputation when he can.

9The model is about the manager's "reputation" for having worked hard, rather than his reputation for high ability. However, it is likely that similar predictions would apply in a setting where the market's uncertainty concerns the manager's ability.
} 
stock price. Thus, managerial rent-seeking is not necessary to obtain the result of investment distortion.

In summary, the papers on hidden investment generally imply that firms will underinvest, because of the desire of managers or of firms to build high reputations. However, in Section III.A.3., we will see that this conclusion relies on a special feature of these models, i.e., only cash flows convey information and high cash flows always convey favorable information. When these features are relaxed and there is good reason to do so - we will see that overinvestment can also occur even when investment is hidden.

\section{Visible Investment}

In many cases, investors can see the manager's investment decision, not just cash flows. Suppose that a firm with a gold mine knows its cost of extracting gold, and that outsiders do not. Consider an all-or-nothing extraction decision. A firm that can extract its gold more cheaply is worth more than investors realize; it can be said to possess a latent asset (Brennan [9]). The latent asset is realized (converted into "universally observable cash flows") at the time of extraction. At that point, its high earnings will resolve uncertainty favorably about its costs. Thus, a firm with a latent asset can improve its reputation by realizing the asset early.

It is interesting to observe that this pressure to realize latent assets prematurely is not a result of visibility bias. Since everyone observes the decision of whether to realize the latent assets, investors can know precisely what part of the current cash flow comes from the latent asset and what part comes from other operations. Realizing a latent asset does not fool investors into thinking that the non-latent asset cash flow is higher than it really is; nor does failing to realize a latent asset make the firm look bad by fooling investors into thinking that non-latent asset cash flows are less than they really are.

The pressure for early realization of positive latent assets (i.e., disinvestment) is exerted by resolution preference. Realizing the latent asset resolves information about the cash flow early. If the latent asset is positive, so that the manager expects good news, then he has an incentive to convey this good news to the market rapidly by realizing the latent asset.

If the latent asset is negative (the gold is very costly to extract), resolution preference pressures the manager to delay extraction to hide the bad news. This suggests that just as positive latent assets are realized too early, negative latent assets will be realized too late. Conversely, one might expect a firm to conceal high costs by inordinately delaying extraction. In Brennan's analysis, this "holding the worst foot backwards" effect does not occur because of mimicry and mimicry-avoidance. Suppose that the mines have been in operation for several years. Some mines with very low costs have already extracted. The mines that are left all have higher costs. The firm, Universal Cash Flow Inc., will extract this year if it has the lowest extraction cost among all remaining firms. By the time this point is reached, Universal Cash Flow Inc. possesses a positive latent asset. The extracting firm is always one that has something favorable to show the market, compared to the market's expectation at that point in time. Thus, all firms, regardless of extraction costs, end up extracting too early (Brennan [9]). This argument is based on the avoidance by high latent asset firms of mimicry by lower latent asset firms. The high latent asset firm is pooled together with inferior firms so long as it fails to extract. The only way the superior firm can distinguish itself is by realizing the latent asset.

Since takeover threats pressure firms to maintain reputation, they should promote early realization of latent assets (Stein [42], see also Laffont and Tirole [28]). This provides support for criticisms of hostile takeovers by corporate leaders and the popular press, such as the claim that takeovers reduce innovation and investment. However, we will see that a more general analysis of managerial reputation-building leads to a wider range of outcomes and different implications about the effects of takeovers.

\section{Cash Flows in the Short-Term and Long-Term}

The previous two subsections have discussed scenarios that imply that firms try to increase short-term cash flows at the expense of long-term cash flows ("short-termism"). However, there are also very reasonable scenarios in which excessive investment occurs. If firms are cash-constrained, then undertaking an investment project can convey favorable information about the manager's expectations about cash flows (as emphasized by Roll [39] in the context of takeovers). Thus, undertaking the investment improves the firm's reputation. Similarly, undertaking an investment can convey favorable information about the quality of the investment project (Trueman [47]). I will discuss this point further below. Finally, investment choices affect resolution of uncertainty, so long-term investments and $R \& D$ can improve the manager's or firm's reputation.

On this last point, as the previous example of the pharmaceutical firm illustrated, increased $R \& D$ can be used to bring forward the resolution of uncertainty about 
the success of an innovative undertaking. A high-quality manager has a stronger incentive to advance resolution than a low-quality one. Thus, the announcement of R\&D that advances resolution can be good news for investors. Reputational pressure therefore leads to excessive $R \& D$ (Hirshleifer and Chordia [22]).

This conclusion differs from the scenarios in the previous two subsections for two reasons. First, the hidden investment and latent assets models (Sections III.A.1. and III.A.2., respectively) assume that resolution of uncertainty is linked solely to the arrival of cash flows. In reality, cash flows are just one type of information among many about the success of a firm's projects. Second, in contrast with these models, managers often cannot perfectly control the timing of news arrival, and do not know with full accuracy how favorable the news will be. Thus, these models would seem to apply better to routine, conventional investments than to innovative projects. For an innovative project, a low-quality manager may defer resolution of uncertainty, hoping to be viewed as a competent manager in a firm where news arrived late owing to external circumstances (see Section II.B.). Since resolution of uncertainty can be delayed by undertaking long-term investment, this scenario raises skepticism about CEOs who demand protection against takeovers to pursue their own long-term goals. While some such managers really will be good (consider Michael Eisner of Disney), on average, such managers will be bad.

Consistent with a reputational pressure in favor of investment, the announcements of capital expenditure increases (aside from the oil industry) are associated with positive abnormal stock returns, on average (McConnell and Muscarella [32]). Similarly, firms that increase their $R \& D$ expenditures, on average, experience positive abnormal stock returns (SEC [40], and Woolridge and Snow [50]). Thus, reputational considerations lead to the implication that there is excessive visible capital investment and investment in R\&D. ${ }^{10}$

Further examination of the scenario in Trueman [47] is instructive (see also Bebchuk and Stole [3]). Trueman [47] examines a firm making a visible decision of whether or not to undertake a project. The manager knows project NPV, but investors do not. All they know is that it lies in a range that includes both positive and negative NPVs. If

\footnotetext{
${ }^{10}$ However, that $R \& D$ may be a very heterogeneous measure. Resolution preference considerations suggest that stock price valuation of increased basic research may be lower than more direct product development activity.
}

only fundamental value considerations mattered, then only firms with positive NPVs would invest. This leads to a situation where the announcement of investment is good news, because it reveals that the firm is in a pool of high-project-value firms rather than low-value firms. But this creates a reputational pressure in favor of investment. If a firm with a slightly negative NPV is concerned with its reputation, it will also invest. A source for this reputational concern is that such a marginal firm can obtain a favorable price for the equity it issues to finance the investment.

The excessive investment of the Trueman [47] model contrasts with Brennan's latent assets model, in which visibility of the investment decision leads to excessive disinvestment (realization of latent assets). In the Trueman model, visibility leads to excessive investment. What is the source of the difference? In the latent asset model, resolution preference draws high firms to disinvest, which reveals their type. They disinvest too early to escape from a pool of lower-valuation firms. In the Trueman model, there is no direct early resolution, so it is investment that allows the firm to jump out of the lower pool.

Since reputational pressures can lead to either shorttermism or long-termism in cash flows, corporate characteristics that change the intensity of reputational pressure can lead to either greater or smaller investment. It has often been claimed that institutional investors exert pressure on firms to reduce $R \& D$ and other investment. The argument given is that $R \& D$ depletes current cash flows. If the stock market is inefficient, it may fail to recognize the likely long-term benefits of R\&D investment. Lang and McNichols [29] have provided some evidence indicating that institutional shareholders sell when performance is poor. However, this does not mean that institutional shareholders force firms to underinvest. In fact, some evidence suggests that high institutional share ownership is associated with higher R\&D expenditures (SEC [40], and Hansen and Hill [18]). This is consistent with the idea that making a visible long-term investment can improve a firm's short-term reputation. On the other hand, it may also be that institutional investors deserve more credit for longterm focus than they have received.

The threat of takeover has also allegedly caused managers to slash investment and reduce innovation. This view is made plausible by the wave of restructurings that occurred during the 1980s, at least some of which was motivated by a desire to avoid being targeted for hostile takeover. However, there is no direct evidence that takeover threats lead to reduced investment. Roll [39] finds that 
the adoption of antitakeover amendments to the corporate charter ("shark repellents") is associated with a subsequent lower probability of being acquired. If takeover pressures caused underinvestment, we would expect that the protection afforded by adopting a shark repellent would cause an increase in R\&D. However, Meulbroek, Mitchell, Mulherin, Netter, and Poulsen [33] find that, after adopting shark repellents, firms on average decrease $R \& D$ expenditures, suggesting that takeover threats may pressure firms toward greater investment.

\section{B. Risk Manipulation}

Several studies have provided evidence suggesting that managers adjust the riskiness of their investment strategies in response to incentives. ${ }^{11} \mathrm{~A}$ manager with incentivebased compensation bears a direct risk that is tied to his firm's prospects. In addition, the manager's reputation is tied to his firm's performance, adding another layer of risk.

It is not surprising therefore that reputation can cause managers to be conservative, i.e., to avoid risk excessively. The next subsection will analyze this point in the context of project initiation. Here, I focus on that fact that for some kinds of projects, there is a subtle time asymmetry between failure and success. Consider again a drug company trying to navigate a new medication across a stormy sea of regulation. The medication may simply not pan out, or it may be developed to the firm's satisfaction, but be rejected by the Food and Drug Administration. If these early hurdles are missed, the game is over, and there is no more uncertainty. On the upside, however, if the medicine is approved, there may remain a great deal of uncertainty about profitability, since the demand for the medicine may be very uncertain until it has been marketed. In other industries as well, early bad news will often lead to project termination, a known bad outcome, while early good news will lead to continuation, an outcome that is good but leaves greater uncertainty about the final outcome.

In other words, there is early resolution of "bad" versus "good" news. But while early "bad news" eliminates uncertainty, early "good news" may still leave much uncertainty about ultimate profitability. In such a setting,

\footnotetext{
${ }^{11}$ DeFusco, Johnson, and Zorn [12] report that after executive stock option compensation plans are introduced, there is, on average, an increase in implied option volatility. Agrawal and Mandelker [1] provide evidence that managers of firms whose stock return variance increases after acquiring another firm, on average, possess greater option compensation than managers of firms whose stock return variance decreases. Hirshleifer and Suh [23] analyze the design of compensation contracts to motivate managers to choose between projects with different risks.
}

Hirshleifer and Thakor [24] show that a manager who is concerned with his reputation will sometimes be too conservative, in the sense that he will avoid projects that are profitable in an expected sense but which have a high probability of early failure. The manager will avoid projects with a high probability of early failure because these indicate early in his career that his ability is low. But a project with a high chance of early failure may also have high upside potential should it succeed. A manager concerned with his reputation will place undue weight on the earliness of the failure, and insufficient weight on the high upside which will only be revealed in the distant future.

In a levered firm, reputational incentives for conservatism help align the interests of creditors and equityholders. Since equityholders possess a call option on underlying firm value, a standard agency problem gives equityholders (or an entrepreneur) an incentive to increase risk to expropriate creditors. The reputational incentive for conservatism can help mitigate this problem. Since takeover threats intensify reputational incentives, we expect that firms that are under greater threat should acquire higher levels of debt. This argument is not based on debt being used as a takeover defense, but rather on the firm's conservatism having the effect of reducing the agency problems of debt. ${ }^{12,13}$ The increase in book leverage during the takeover boom of the 1980s is consistent with this implication.

This argument is related to a well-known model of Diamond [14] on the incentives of debt-financed entrepreneurs. For such an entrepreneur, the defaulting on debt reveals bad news, while repaying the loan does not reveal just how high profits really were. Again, the reputational asymmetry between early downside revelation and a lack of upside revelation gives the manager an incentive to be conservative, in the sense of favoring too "safe" projects. Again, a safe project is defined as one with a low probability of early visible failure.

Rather than distorting the firm's investment decision, a manager may want to reduce his reputation risk by using derivative securities to hedge on corporate account. In the model of DeMarzo and Duffie [13], there is a benefit to the manager from hedging if outsiders cannot observe the

\footnotetext{
${ }^{12}$ Thus, the presence of takeover threats can make shareholders better off ex ante.

${ }^{1.3}$ Diamond [14] has shown that this agency problem is somewhat ameliorated in a multiperiod setting in which entrepreneur/borrowers (equityholders) care about protecting an already-developed reputation for creditworthiness.
} 
firm's risk-exposure, and if the firm's hedging profits are aggregated with other revenues. (If hedging profits are accounted for separately, then investors can ignore hedging in forming their evaluation of the manager's performance.) Hedging can indirectly bring about real improvements in the firm's investment decisions, because the firm's profits become more informative about whether the project should be abandoned if a hedge is used to optimally filter away external factors. Knowing the manager's ability is useful in deciding whether to replace him. Thus, the ability to hedge can lead to improved investment decisions.

\section{Projects Transitions}

The personal concerns of managers are often paramount in decisions of whether to undertake a major project, or whether to terminate an ongoing one. This is particularly the case if the transition is associated with a major change in the firm's strategy. Large acquisitions are often lifetime events that can make or break a manager's career.

One effect of sharp shifts in firm strategy, such as acquisitions to exploit synergy, international diversification, or fundamental restructuring, is that uncertainty is created about the firm's future that may take a long time to be resolved. As such, it makes it difficult to evaluate a manager's performance until considerable time has passed. In contrast, a bust-up takeover (for example) should lead to profits from the sale of divisions fairly rapidly, if it is to be successful. The analysis of resolution preference in Section II.B. implies that low-quality managers or organizations are more likely to defer resolution of uncertainty. Thus, the announcement of actions that defer resolution implies a negative average bidder stock price reaction. This is consistent with many studies indicating that the stock market does not regard takeover bids as, on average, being good deals for the bidder (for tender offers, an average abnormal stock price reaction of close to zero associated with takeover contests over several decades, and negative in the 1980s; see Bradley, Desai, and Kim [8], Roll [39], and Bhagat and Hirshleifer [5]). It is also consistent with Mørck, Shleifer, and Vishny's [34] finding that the bidder's stock returns are, on average, lower in acquisitions of unrelated firms than in acquisitions of related firms, and are lower when the firm acquires a rapidly growing target. The latter type of acquisition is also probably often associated with strategic business shifts on the part of the bidder.

As indicated in point II.A.2.(ii) earlier, a risk-averse manager may avoid projects that resolve uncertainty be- cause this adds risk to his reputation. Holmstrom and Ricart i Costa [26] analyze the design of a managerial compensation contract to deal with this problem. Since the firm can bear risk more cheaply than the manager, the solution is a contract that protects the manager partially on the downside. If this protection is mild, he will still avoid risk, but not as fervently. If this protection is strong, the manager is like the possessor of an out-of-the-money call option. He has little to lose on the downside, and everything to gain on the upside, so he will be too eager to undertake risky projects. If the project manager is not the boss, his superior can counter the overinvestment propensity of the project manager by rationing capital. ${ }^{14}$

In the discussion above, the action of not undertaking a project is safe for the manager because no information arrives to update beliefs about the quality of the manager. Consider instead the choice between investing in a longterm project versus a short-term project. If resolution of uncertainty will occur late for the long-term project, then similar reasoning implies that a risk-averse manager will prefer the long-term project, unless a compensation scheme is designed especially to modify his project incentives. Thus, reasoning similar to Holmstrom and Ricart i Costa's can imply an excessive preference for long-term investment even by unprotected managers.

Holmstrom [25] gives an ingenious argument as to why managers may be too reluctant to undertake projects, based upon the premise that the manager has better information about project quality than do outsiders. Suppose that the probability that the project will succeed depends on the project quality $q$, and that the project should be undertaken only if $q>c$, where $c$ is an appropriate cutoff. The manager's quality may be high or low, but for simplicity assume that neither he nor outsiders know which is the case. A high-quality manager's project is more likely to succeed than a low-quality manager's, holding constant project quality.

Suppose that investors thought that the manager would do the right thing, investing whenever $q>c$. Now consider a manager whose information indicates that $q$ is just barely above $c$. If he invests, then outsiders don't know whether $q$ was a little above $c$ or far above $c$. Since outsiders think that the project may be of very high quality, they are overestimating the project quality and its contribution to

\footnotetext{
${ }^{14}$ Capital rationing also occurs in a reputation model under risk neutrality. As discussed earlier, resolution preference and mimicry effects can lead to overinvestment; Bethel [4] demonstrates that capital rationing can be an effective counter to this problem.
} 
probability of success. Thus, should the investment fail, outsiders will draw an unduly adverse inference about the manager's quality. So if the project's quality is only marginally good, the manager will not undertake the project. If outsiders rationally foresee this, then everyone recognizes that the cutoff $c$ is slightly raised. Now even a slightly better project (slightly higher $q$ ) becomes marginal, so it too will be rejected. At this point, it doesn't take a weatherman to see how the wind is blowing. The cutoff keeps climbing and the whole equilibrium unravels. The conclusion of this reasoning is that regardless of quality, the project is always rejected! ${ }^{15}$

The termination of a project also has major effects on managers' reputations. Selling a division could be viewed as a concession of failure, in which case a manager would be reluctant to do so. Kanodia, Bushman, and Dickhaut [27] provide a model in which managers escalate bad projects instead of terminating them. However, there are also reasons for selling a division that imply that the announcement of a divestiture will have a favorable reputational impact. The division may be worth more than investors have realized, and hence the sale is a realization of a positive latent asset. Alternatively, the sale of a division can reveal that the manager plans to devote himself to even better project opportunities that have become available (Boot [7]).

\section{Deviants, Fads, and Conformism}

Since a firm's profitability depends on many factors other than the manager's ability, it is not easy to evaluate a manager's performance. An invaluable tool for this purpose is to compare the firm to others that seem roughly comparable. By running a horse race, the external factors are (partially) filtered out, leaving differences in managerial ability to explain the relative performance. Compensation plans can explicitly be based upon relative performance, but even if they are not, the manager's reputation will depend on all the information available to investors, which includes both the actions chosen (if visible) and the profitability (when it becomes known) of competitors.

Comparing actions and outcomes of different managers is no panacea, however. Relative comparisons create their own problems, which take the form of biases in favor of either conformist or deviant behavior. We will see that which of these occurs depends on the quality of the man-

\footnotetext{
${ }^{15}$ This suggests that in such a scenario, the firm should design a compensation contract that gives the manager some protection to persuade him to undertake projects.
}

ager, and on whether the investment decisions of the managers are visible, or only the profit outcomes.

The comparison of actions alone tends to lead to conformism. This is illustrated by the advertising slogan, "No manager ever got fired for buying IBM." Alas, in this changing world, even temporary islands of safety can become precarious.

As another example, if a bank stands out as a large lender to an LDC that defaults, the reputational damage to its manager may be greater than if it is one among several major lenders. Suppose that managers are either smart or dumb, and for simplicity assume that managers do not know their own abilities. A smart manager observes an information signal that indicates whether an investment project should or should not be undertaken. A dumb manager also observes a signal, but this signal is actually pure noise, and so is useless for evaluating the project. The key assumption is that for two smart managers, their signals are positively correlated. In other words, if the right thing to do is invest, both managers tend to observe favorable signals, and if the right thing to do is reject the project, two smart managers will tend to observe adverse signals. Thus, smart managers will tend to do the same thing. Conversely, if one or both managers are dumb, it is assumed that their signals are uncorrelated, because dumb managers are observing pure random noise. Suppose now that the first manager adopts the project, and the second manager is deciding what to do. If he deviates by rejecting, then investors will infer that at least one of the managers is dumb. Investors don't know which, so this raises significant skepticism about the second manager. If instead he conforms by adopting the project, then investors cannot reject the possibility that both managers are smart. Similar reasoning applies if the first manager adopted the project. Thus, the correlation of signals among the smart creates a pressure to conform (Scharfstein and Stein [41]).

There is one important qualification, however. If dumb managers are prone to correlated errors, then the reasoning can be reversed. For example, if dumb managers are too credulous about mistaken rumors or the "conventional wisdom," and smart managers are more critical, then it may be dumb managers whose signals are more highly correlated. ${ }^{16}$ To take another example, if the mistake that dumb managers make is to use a popular but invalid capital

\footnotetext{
${ }^{16}$ Similarly, if dumb managers use popular but crude rules of thumb in project evaluation, while smart managers make the effort to perform individual in-depth analyses, then dumb managers may make assessments that are more highly correlated than those of smart managers.
} 
budgeting technique (such as the IRR criterion), then their assessments of projects may still be highly correlated.

A different argument is based on hidden investment choices and profits that become visible early. Suppose now that managers know their own abilities, and that higher ability increases profit. The manager is faced with a choice between a standard project, which is subject to a risk that is common between firms, and an innovative project whose risk will be borne by the adopting firm but not by the bulk of firms who undertake the standard project. Since the project choice is not directly observable, the benchmark for comparison is the profitability of the industry standard chosen by most managers. Assume that a manager has a strong aversion to severe underperformance relative to the industry standard. For example, he can be fired. Then a very low-ability manager is almost sure to be fired if he chooses the standard project. He may as well gamble on the innovative project. If he is fortunate, this way he can avoid being fired. A manager of intermediate ability can afford to select the standard project, because he is likely to perform well enough to be retained. An exceptionally good manager can afford to innovate, because even if the innovative project is a disappointment, his high ability will raise profitability enough to avoid severe underperformance compared to the industry benchmark (Zwiebel [51]).

This separation is analogous to the Teoh [44] model of auditor changes by client firms who wish to maximize profits and to avoid qualified opinions. In her model, "hopeful switches" are made by client firms doing poorly, who expect a qualified opinion from the current auditor. "Faint-hearted retentions" of the incumbent auditor are made by firms who are doing well enough to expect a clean opinion from the incumbent auditor, but who would face a risk of qualification from an untried auditor. "Macho switches" may be made to signal confidence by firms doing so well that they can be confident of a clean opinion from a new auditor as well as the incumbent auditor. Teoh [44] has an additional category, which does not correspond to any of those in Zwiebel's model, i.e., "lost cause" retentions. These are firms doing so poorly that even if they switch, they are unlikely to get a clean opinion. This suggests that in Zwiebel's analysis, if there were a fixed cost imposed on the manager for innovating, he would also obtain "lost cause" firms who would stick to the standard project because even the innovative project leads to little hope of avoiding being fired.

Managerial reputation-building is not the only possible explanation for conformism by managers in their investment decisions. A possible alternative is the theory of informational cascades. In the cascades model of Bikhchandani, Hirshleifer, and Welch [6], managers make similar investment decisions in sequence. ${ }^{17}$ Each manager observes a signal about the profitability of the investment, and can observe the actions but not the signals of previous managers. At some point in the sequence, a manager will rationally ignore his own information signal, because his individual signal is dominated by the accumulated information implicit in the actions of earlier managers. For example, if a dozen managers have rejected the project, even if the manager has observed a favorable indication about it, he will also reject the project because he infers that some of the earlier managers observed adverse signals. (Some of the later managers may just be following the crowd, like him.)

There is one important distinction between the implications of the cascades theory and current reputationbased models. The reputation-based models promote stability, because of pressures on most or all managers to conform to the current standard. Thus, reputation effects probably do not fully explain sudden investment shifts such as takeover waves. The cascades theory predicts fragility of social behavior, hence the title of the [6] paper: "A Theory of Fads, Fashion, Custom and Cultural Change as Informational Cascades." Fragility in the cascades model occurs because each manager keeps using his own information signal until a point is reached at which the decision of some manager ("individual $n$ ") adds just enough information to the investment history that the next manager $(n+1)$ becomes willing by a small margin to ignore his own signal and follow the others. At this point, manager $n+1$ 's investment decision is uninformative, so all later managers do the same thing. This situation is an informational cascade. After the cascade starts, individuals are just barely willing to ignore their own signals. Thus, if there is even a very small shock to the system (a shift in the expected value of the investment, or a news disclosure), then investment decisions can shift radically. ${ }^{18}$

\section{Conclusions and Recommendations for Investment Policy}

Since this article has referred to "manipulation" and "distortions" associated with reputation-building, the

\footnotetext{
${ }^{17}$ See also related work by Welch [46] and Banerjee [2].

${ }^{18}$ For interesting applications, see Lee [31] on informational cascades as an explanation for stock market crashes, and Chamley and Gale [10] on investment fads.
} 
reader may be tempted to believe that the managerial concern for reputation is a problem that has primarily negative consequences. This is by no means necessarily the case, for three reasons:

(i) Reputation-building can pressure the manager to act more in the interest of creditors, instead of just equityholders. This can help mitigate the investment inefficiencies associated with risk-shifting by equityholders (see Section III.B).

(ii) Reputation-building can help pressure managers to work hard (Gibbons and Murphy [16]). This can be useful if the manager's reputation depends on information that is hard to write explicit contracts on. ${ }^{19}$

(iii) Because of externalities and tax-induced distortions, the level of investment even without reputational incentives will in general be inefficient. Reputational "distortions" will sometimes help offset these problems.

To illustrate the last point, consider R\&D. It is often argued that there is underinvestment in $R \& D$ because of positive externalities in research. The analysis here identified cases in which reputation pressures firms to overinvest in $\mathrm{R} \& \mathrm{D}$, from the viewpoint of equityholders. Given externalities, this could be a good thing.

We have also seen that reputation can lead to pressures for higher or lower investment levels in different scenarios. Given arbitrary depreciation rules, investment tax credits, and so on, we would expect investment levels to be inefficient both overall and as allocated between industries and firms. Reputation effects probably act to help in some cases and hurt in others, in a way that would require careful analysis.

These points are important for the debate as to the desirability of takeovers, or more generally, of making top corporate management subject to the monitoring of the board of directors and institutional investors. Since the effects of reputation-building can operate in different directions in different cases, and since there are nonreputational distortions already present, current theory and empirical work on reputation-building does not present a strong general conclusion about the market for takeovers and other forms of corporate control.

\footnotetext{
${ }^{19}$ Stock and option compensation pays the manager based on the firm's reputation. But the manager's and the firm's reputation, while very closely related, will sometimes differ. See, e.g., the discussion of Holmstrom [25] in Section III.C. of this article.
}

What we do see is that a large variety of managerial investment policies are influenced by the manager's incentive to build his personal reputation and that of his firm. Reputation affects the firm's risk-taking, what projects it undertakes and when it terminates them, whether it tries to obtain resolution of its project uncertainty early or late, and whether the firm's investment policy conforms to others in the industry or diverges. Thus, the analysis of managerial reputation-building is crucial for a scientific understanding of how firms make investment decisions, and for the optimal design of compensation contracts and capital budgeting procedures to motivate profitable investments.

We have seen that the effect of managerial reputationbuilding on investment depends upon a variety of factors. These include: the set of possible projects available to the firm, how soon investors can observe the profitability of an undertaken project, whether the investment policy is visible to outsiders, how tolerant the manager is of risk, and his self-assessment of his management ability. Some recent theoretical research in this area has supported popular allegations that institutional investors and the market for corporate control have pressured U.S. managers to be too conformist, conservative, and concerned about shortterm cash flows. Taken as a whole, however, the theoretical and empirical research on reputation-building neither substantiates nor refutes these allegations. We have seen that the pressure to engage in reputation-building will sometimes lead to nonconformity, risk-taking, and overinvestment. Since empirical work on this topic has lagged behind the recent proliferation of theoretical work, it is to be hoped that further empirical analysis can help clarify these issues.

I conclude by summarizing some of the major consequences for investment choices of managers' desire to build and maintain reputation.

- If the investment policy ${ }^{20}$ is visible to the market, then greater investment tends to be a favorable indicator of managerial and firm quality, implying that firms will tend to overinvest. However, the outcome of the investment as well as the act of investing affect reputation. Since the manager may have either favorable or adverse information about the outcome, the early revelation of outcome can lead to either underinvestment or overinvestment. Furthermore, a manager must be concerned not just with how his project will be viewed, but how this compares with investors' current assessments. If the market's prior

\footnotetext{
${ }^{20}$ That is, whether the project is undertaken, the type of project selected, and the amount invested in the project.
} 
expectation about the quality of available projects is sky high, a good but not outstanding project may be suppressed.

- Latent assets will generally be realized too early. In other words, if a manager owns an asset from which he can generate more cash flows today than the market expects, then he has an incentive to convert the asset into cash early even if value would be maximized by holding on to the asset and "harvesting" it later. However, if a manager has imperfect control over when the project outcome will be resolved, the manager may also defer cash flows in order to conceal a likely failure.

- Competent managers and superior organizations will favor investment policies and projects that lead to early resolution of uncertainty about outcome more than do incompetent managers and organizations.

- The tendency for complete failure to become visible early, and degrees of success to manifest themselves only later, tends to bring about conservative investment choices. ${ }^{21}$

- There are pressures for managers to conform to the investment choices of other firms in the industry, depending on whether the project choice and the profitability of the project are observable early. If the manager knows his own ability, he may deviate to more innovative project choices if he is so bad he has nothing to lose, or if he is so good that he can afford to take chances.

\section{References}

1. A. Agrawal and G.N. Mandelker, "Managerial Incentives and Corporate Investment and Financing Decisions," Journal of Finance (September 1987), pp. 823-837.

2. A. Banerjee, "A Simple Model of Herd Behavior," Quarterly Journal of Economics (1992), pp. 797-818.

3. L. Bebchuk and L. Stole, "Do Short-Term Managerial Objectives Lead to Under- or Over-Investment in Long-Term Projects?," Harvard Law School Discussion Paper No. 87, February 1991.

4. J. Bethel, "Project Forecasting, Job Mobility, and Capital Rationing," Working Paper, Harvard Business School, June 1990.

5. S. Bhagat and D. Hirshleifer, "Market-Based Estimates of Value Gains from Takeovers: An Intervention Approach," UCLA AGSM Working Paper No. 19-92, March 1993.

6. S. Bikhchandani, D. Hirshleifer, and I. Welch, "A Theory of Fads, Fashion, Custom, and Cultural Change as Informational Cascades," Journal of Political Economy (October 1992), pp. 992-1026.

${ }^{21}$ However, the incentives for overinvestment discussed earlier can lead to excessive risk-taking as well.
7. A. Boot, "Why Hang on to Losers: Divestitures and Takeovers," Journal of Finance (September 1992), pp. 1401-1423.

8. M. Bradley, A. Desai, and E.H. Kim, "Synergistic Gains from Corporate Acquisitions and their Division Between Stockholders of Target and Acquiring Firms," Journal of Financial Economics (May 1988), pp. 3-40.

9. M.J. Brennan, "Latent Assets," Journal of Finance (July 1990), pp. 709-730.

10. C. Chamley and D. Gale, "Information Revelation and Strategic Delay in Irreversible Decisions," Working Draft, Boston University, July 1992.

11. P.K. Chaney, T.M. Devinney, and R.S. Winer, "The Impact of New Product Introductions on the Market Value of Firms," Journal of Business (October 1991), pp. 573-610.

12. R. DeFusco, R. Johnson, and T. Zorn, "The Effect of Executive Stock Option Plans on Stockholders and Bondholders," Journal of Finance (June 1990), pp. 617-627.

13. P.M. DeMarzo and D. Duffie, "Corporate Incentives for Hedging and Hedge Accounting," Working Paper, Stanford University and Kellogg School, March 1993.

14. D.W. Diamond, "Reputation Acquisition in Debt Markets," Journal of Political Economy (August 1989), pp. 828-862.

15. P.H. Dybvig and J.F. Zender, "Capital Structure and Dividend Irrelevance with Asymmetric Information," Review of Financial Studies (Vol. 4, No. 1, 1991), pp. 201-220.

16. R. Gibbons and K.J. Murphy, "Optimal Incentive Contracts in the Presence of Career Concerns: Theory and Evidence," Journal of Political Economy (June 1993), pp. 468-505.

17. K. Hagerty, A. Ofer, and D. Siegel, "Managerial Compensation and Incentives to Engage in Far-Sighted Behavior," presented at AFA Meetings, Washington, D.C., December 1990 (October 1990 version).

18. G.S. Hansen and C.W.L. Hill, "Are Institutional Investors Myopic? A Time-Series Study of Four Technology-Driven Industries," Strategic Management Journal (1991), pp. 1-16.

19. M. Harris and B. Holmstrom, "A Theory of Wage Dynamics," Review of Economic Studies (July 1982), pp. 315-333.

20. M. Harris and A. Raviv, "A Sequential Signalling Model of Convertible Debt Call Policy," Journal of Finance (December 1985), pp. 1263-1281.

21. D. Hirshleifer, "Reputation, Incentives and Managerial Decisions," in the New Palgrave Dictionary of Money \& Finance, P. Newman, M. Milgate, and J. Eatwell, (eds.), Macmillan Press Limited, London, Stockton Press, New York, 1992, pp. 332-337.

22. D. Hirshleifer and T. Chordia, "Managerial Incentives to Manipulate the Timing of Project Resolution," UCLA AGSM Working Paper No. 21-90, March 1992.

23. D. Hirshleifer and Y. Suh, "Risk, Managerial Effort, and Project Choice," Journal of Financial Intermediation (1992), pp. 308-345.

24. D. Hirshleifer and A.V. Thakor, "Managerial Conservatism, Project Choice, and Debt," Review of Financial Studies (Vol. 5, No. 3, 1992), pp. $437-470$.

25. B. Holmstrom, "Managerial Incentive Problems - A Dynamic Perspective," in Essays in Economics and Management in Honour of Lars Wahlbeck, Helsingors, Swedish School of Economics, 1992, pp. 177-208.

26. B. Holmstrom and J. Ricart i Costa, "Managerial Incentives and Capital Management," Quarterly Journal of Economics (November 1986), pp. 835-860.

27. C. Kanodia, R. Bushman, and J. Dickhaut, "Escalation Errors and the Sunk Cost Effect: An Explanation Based on Reputation and 
Information Asymmetries," Journal of Accounting Research (Spring 1989), pp. 59-77.

28. J.-J. Laffont and J. Tirole, "Repeated Auctions of Incentive Contracts, Investment, and Bidding Parity with an Application to Takeovers," Rand Journal of Economics (Winter 1988), pp. 516-537.

29. M. Lang and M. McNichols, "Institutional Investment, Corporate Earnings and Managerial Incentives," Graduate School of Business, Stanford University, October 1991

30. A. Lee, Call Me Roger, Chicago/New York, Contemporary Books, 1988.

31. I.H. Lee, "Market Crashes and Informational Cascades," Mimeo, September 1992.

32. J.J. McConnell and C.J. Muscarella, "Corporate Capital Expenditure Decisions and the Market Value of the Firm," Journal of Financial Economic's (September 1985), pp. 399-422.

33. L.K. Meulbroek, M.L. Mitchell, J.H. Mulherin, J.M. Netter, and A.B. Poulsen, "Shark Repellents and Managerial Myopia: An Empirical Test,".Journal of Political Ec onomy, (October 1990), pp. 1108-1117.

34. R. Mørck, A. Shleifer, and R.W. Vishny, "Do Managerial Objectives Drive Bad Acquisitions?," Journal of Finance (March 1990), pp. $31-48$.

35. M.P. Narayanan, "Observability and the Payback Criterion,"Journal of Business (July 1985), pp. 309-323.

36. M.P. Narayanan, "Managerial Incentives for Short Term Results," Journal of Finance (December 1985), pp. 1469-1484.

37. J.M. Paul, "Managerial Myopia and the Observability of Future Cash Flows," Working Paper, University of Michigan, October 1992.

38. J. Pound, "The Effects of Antitakeover Amendments on Takeover Activity: Some Direct Evidence," Journal of Law' and Economics (October 1987), pp. 353-367.

39. R. Roll, "The Hubris Hypothesis of Corporate Takeovers," Journal of Business (April 1986), pp. 197-216.
40. Securities and Exchange Commission, Office of Economic Analysis, "Institutional Ownership, Tender Offers, and Long-Term Investments," April 1985.

41. D.S. Scharfstein and J.C. Stein, "Herd Behavior and Investment," American Economic Review (June 1990), pp. 465-479.

42. J. Stein, "Takeover Threats and Managerial Myopia," Journal of Political Economy (February 1988), pp. 61-80.

43. J. Stein, "Efficient Capital Markets, Inefficient Firms: A Model of Myopic Corporate Behavior," Quarterly Journal of Economic's (November 1989), pp. 655-670.

44. S.H. Teoh, "Auditor Independence, Dismissal Threats, and the Market Value of Switches," Journal of Accounting Research (Spring 1992), pp. 1-23.

45. A.V. Thakor, "Investment Myopia and the Internal Organization of Capital Allocation Decisions," Iournal of Law, Economics and Organization (Spring 1990), pp. 129-154.

46. A.V. Thakor, "Information, Investment Horizon, and Price Reactions," Journal of Financial and Quantitative Analysis, forthcoming.

47. B. Trueman, "The Relationship Between the Level of Capital Expenditures and Firm Value,"Journal of Financial and Quantitative Analysis (June 1986), pp. 115-130.

48. I. Welch, "Sequential Sales, Learning and Cascades," Journal of Finance (June 1992), pp. 695-732.

49. J.R. Woolridge, "Competitive Decline and Corporate Restructuring: Is a Myopic Stock Market to Blame?," Journal of Applied Corporate Finance (1989).

50. J.R. Woolridge and C.C. Snow, "Stock Market Reaction to Strategic Investment Decisions," Strategic Management Journal (1990), pp. 353-363.

51. J. Zwiebel, "Corporate Conservatism. Herd Behavior and Relative Compensation." Mimeo, Stanford University, October 1990. 